\title{
Online System Policy And Cyber Notary In Facing The Impact Of Covid-19
}

\author{
Ahmad Farid Bisyarohatie*), Umar Ma'ruf ${ }^{* *}$ and Widhi Handoko ${ }^{* * *}$ \\ ${ }^{*}$ Faculty of Law, Universitas Islam Sultan Agung (UNISSULA) Semarang, E-mail: \\ faridbiayarohatie99@gmail.com \\ ${ }^{* *)}$ Faculty of Law, Universitas Islam Sultan Agung (UNISSULA) Semarang, E-mail: \\ umar@unissula.ac.id \\ ${ }^{* * *)}$ Faculty of Law, Universitas Islam Sultan Agung (UNISSULA) Semarang, E-mail: \\ widhihandoko@unissula.ac.id
}

\begin{abstract}
The purpose of this study is to describe and explain the reasons for the implementation of the online system and Cyber Notary has not been held in relation to Legal Policy in Facing the Impact of Covid-19 on Notary Performance. Describe the obstacles faced and to provide solutions to notaries in implementing an online and cyber notary system in Facing the Impact of Covid-19 on Notary Public Performance. The approach method in this research is juridical empirical. The specification used in this research is descriptive analytical. The data analysis method was carried out qualitatively. The results of this study are the application of an online system to cyber notary in Surakarta, which still requires more indepth dissemination of security and effectiveness in the use of online systems and cyber notaries, as well as the obstacles faced in implementing the online system and cyber notary policies in dealing with the impact of covid-19 in the city of Surakarta, there are still conflicting rules between Article 15 UUJN and Article 16 UUJN, linked to Articles 11 and 12 of Act No. 11 of 2008 and Act No. 19 of 2016 concerning Electronic Information and Transactions (UU ITE and PUU ITE).
\end{abstract}

Keywords: Covid-19; Cyber; Notary.

\section{Introduction}

Law of the Republic of Indonesia Number 2 of 2014 concerning Amendments to Act No. 30 of 2004 concerning the Position of Notary which was promulgated on January 15, 2014 State Gazette of the Republic of Indonesia of 2014 Number 3 
(Amendment Law on UUJN). In Article 1 number 1 of the Amendment Law on UUJN which states that notaries are public officials who have the authority to make authentic deeds and other powers as referred to in this Law. Based on the description above, it can be stated that a notary is a public official who has the authority to make an authentic deed which is not exempted from other officials. These other officials include Civil Registry Officers, PPAT, Court Clerks, Bailiffs, and so on. An authentic deed made by a notary contains the contents of the act, agreement, provisions that require a notary as a public official. The deed made by the Notary is a declaration of the wishes of the parties before the Notary to express the will in an authentic deed.

If it is related to Islamic Law, the existence of a Notary and PPAT is very much needed, which refers to the proof of the Al-Qur'an in Surah Al Baqarah (2) verse 282 which reads: "O people who believe, if you are believers, don't in cash for a specified time, let you write it down. And let a writer among you write correctly. And the writer should not be reluctant to write it as Allah taught him, so let him write, and let the person in debt claim (what is to be written), and let him fear Allah, his God, and let him not deduct at all from his debt ". ${ }^{1}$

The verse explains that a Notary is required to be able to act mandatefully towards his duties without any reduction or addition in recording, because the responsibility of a Notary and PPAT is not only to the parties but also to Allah SWT. Notaries in carrying out their duties receive supervision. Provisions for notary supervision refer to the Circular of the Supreme Court of the Republic of Indonesia Number 2 of 1984 concerning Procedures for Supervision of Notaries, as well as Joint Decree of the Chief Justice of the Supreme Court and Minister of Justice Number KMA / 006 / SKB / VII / 1987 concerning Procedures for Supervision, Action and Self-Defense of Notaries.

Since the enactment of the notary office, the supervision of notaries who previously served at the Supreme Court through the local District Court, has been transferred to the Minister of Law and Human Rights of the Republic of Indonesia through the Regional Supervisory Council. Notaries have an association organization called INI (Indonesian Notary Association) which is a forum for association / organization for notaries, established since July 1, 1908, recognized as a legal entity (rechtpersoon) based on Gouvernements Besluit (Government Decree) dated September 05, 1908 Number 9, is the only unifying forum for all and everyone who holds and carries out his / her duties as a General Officer. As a Follow-up to the History of the Notary Association. Then the Laws and Regulations Issued, namely:Notary's Articles of Association and By laws.

\footnotetext{
${ }^{1}$ Ministry of Religion of the Republic of Indonesia, 2012, Al Baqarah (2) verse 282, Al-Qur'an and its translation (Bandung: PT. Mizan Buaya Kreativa), p. 88.
} 
The implementation of the duties and positions of notary public and PPAT is currently being hampered by the Covid-19 Virus Pandemic which is often referred to as the Corona virus, currently the world is being shaken by its outbreak. How not, the disease caused by this latest type of coronavirus has claimed thousands of lives. In an effort to suppress the spread of the Corona virus, the government encourages the public to carry out social distancing or often called social distancing.

Coronaviruses are a large family of viruses that cause disease in humans and animals. In humans, it usually causes respiratory infections, from the common cold to serious illnesses such as Middle East Respiratory Syndrome (MERS) and Severe Acute Respiratory Syndrome (SARS). A new type of coronavirus that was discovered in humans since the outbreak occurred in Wuhan China, in December 2019, was then named Severe Acute Respiratory Syndrome Coronavirus 2 (SARSCOV2), and causes Coronavirus Disease-2019 (COVID-19).

COVID-19 is caused by SARS-COV2 which belongs to the same large family of coronaviruses that caused SARS in 2003, only with a different type of virus. Symptoms are similar to SARS, but the SARS death rate $(9.6 \%)$ is higher than COVID-19 (less than 5\%), even though the number of COVID-19 cases is far more than SARS. COVID-19 also had a wider and faster spread to several countries than SARS. Because the virus is all people have to apply social distancing. According to the Centers for Disease Control and Prevention (CDC), the meaning of the term 'social distancing' or 'social restrictions' is avoiding public places, staying away from crowds, and maintaining an optimal distance of 2 meters from other people. With the distance, the spread of this disease is expected to be reduced, the application of social distancing is very influential on the performance of notaries, especially in the city of Surakarta.

Based on the background of the problem above, the purpose of this study is to describe and explain the reasons for the implementation of the online system and Cyber Notary has not been held in relation to Legal Policy in Facing the Impact of Covid-19 on Notary Performance. Describe the obstacles faced and to provide solutions to notaries in implementing an online and cyber notary system in Facing the Impact of Covid-19 on Notary Public Performance.

\section{Research Methods}

This research method uses an empirical juridical approach, data collection using literature study and field research through interviews. The specifications used in 
this study are analytical descriptions that are intended to provide as accurate data as possible about a condition or other symptom and it is hoped that this research can provide a clear picture of the Online System Policy and Cyber Notary in Facing the Impact of Covid-19 in the City of Surakarta. The data were analyzed qualitatively and then presented descriptively. Research problems inanalysis with legal certainty theory and legal protection theory.

\section{Results and Discussion}

\subsection{The reasons for the implementation of the online system and Cyber Notary have not been held related to Legal Policies in Facing the Impact of Covid-19 on Notary Performance}

In the implementation of services in the legal field, especially PPAT notaries, are very disturbed by the existence of Covid-19, especially sub-districts and villages that are carrying out area lockdowns and Large-Scale Social Restrictions, according to the author, studied from the theory of legal certainty, especially those related to gathering restrictions and restrictions social must refer to statutory regulations, it is clear that the application of social restrictions on a large scale in an area must be based on a decision from the Minister of Health based on a request from the Regional Head, this is done as a result of the covid19 virus which continues to attack many lives. The number of confirmed covid patients continues to increase as well as the number of fatalities, the cumulative data on cases as of January 2021 has almost touched 7,000 cases, to be precise there are 6,955 residents of Solo who have been confirmed positive for corona. In details, 4,395 people returned / recovered, 1,954 people were isolated independently, 275 people were hospitalized, and 331 people died. The state has an obligation to respect, protect. $^{2}$ Therefore, in an emergency situation as determined by WHO, the Government of Indonesia clearly has to follow up with the best efforts.

The spread of this virus is partly due to the fact that many areas have not implemented the large-scale social restriction status that has been stipulated by the Minister of Health, but this does not mean that the security forces have arbitrarily carried out dissolution actions, this is against the guarantee of the right to freedom. assembly, where the right to freedom of assembly is guaranteed by law and can be limited in accordance with legal standards. Apart from being regulated in Article 28 of the 1945 Constitution, the right to associate and assemble has also been guaranteed in Article 28E paragraph (3) of the 1945 Constitution and Article 24 paragraph (1) of the Human Rights Law and Article

\footnotetext{
${ }^{2}$ https://surakarta.go.id/?page_id=10806, accessed on January 2, 2021 at 18.30 .
} 
28E paragraph (3) of the 1945 Constitution. Everyone has the right to freedom of association. get together, and issue opinions.

The restrictions on association and assembly also greatly affect the performance of otaris in Surakarta, but this can be overcome by technological advances in the use of digital signatures accompanied by the draft Law (UU) No. 11 of 2008 concerning Information and Electronic Transactions (ITE). This law regulates a system of proof from information, documents, and electronic signatures, which is detailed and outlined in Articles 5 to 12. Many users of digital services, in this case cyber notary in Surakarta, especially PPAT notaries, still think that policies and The legal rules regarding service and signing of documents must adhere to what is stipulated in the Law on the Position of Notary Public and applicants must remain present and present at the notary's office. ${ }^{3}$

For some notaries and PPAT, especially in the City of Surakarta, who strictly adhere to the Law on Notary Position, signing of files without appearing or being witnessed directly by a notary violates the regulations of the Notary Position Law. ${ }^{4}$ In Indonesia, especially the city of Surakarta, they still do not really understand the use of digital signatures so it is not surprising that there are still many individuals, agencies and companies who doubt their performance and security, for some notary offices face-to-face meetings are still maintained even though they are currently in a Covid-19 pandemic situation. continue to increase. By establishing health protocols and maintaining distance, applicants who wish to use the services of a PPAT notary must still come to the office. ${ }^{5}$

Lack of knowledge and experience about the use of technology by notaries, according to the author, can hinder the provision of legal certainty and protection for people who need notary services. The use of computers in making deeds and during the online legal entity registration process is a sign that notaries in Indonesia have started using computer systems and the internet in carrying out their duties, but in the case of making a Partij Deed it seems impossible or difficult to do it by cyber notary by a notary in the city of Surakarta, this is because the notary must see and hear directly in the reading and signing carried out by the parties, the witnesses and the notary itself. Certainty about a deed is

\footnotetext{
${ }^{3}$ Interview with Ebora Enny Sutanti, Notary and Surakarta City Land Deed Maker, December 10, 2020 at $14: 15$

${ }^{4}$ Interview with Rofian Amianto, Notary and Surakarta City Land Deed Making Official, December 11,2020 at 09.00

${ }^{5}$ Interview with Suparno, Notary and Land Deed Maker Officer for Surakarta City, December 14, 2020 at 10.00
} 
very important because what is stated in the deed is valid evidence against the parties who made the deed or those who have rights and apply to the public, unless there is other evidence which states otherwise.

According to the author, it is very unfortunate about the civil evidentiary law in Indonesia, which legally and formally has not been able to accommodate documents or electronic information as evidence in resolving disputes through courts. Nonetheless, Indonesia has taken actions that lead to electronic documents as valid evidence, for example electronic means as storage media for corporate documents as regulated in Act No. 8 of 1997 concerning Company Documents. ${ }^{6}$

\subsection{Constraints faced and to provide solutions to notaries in implementing an} online and cyber notary system in Facing the Impact of Covid-19 on Notary Public Performance

The use and application of cyber notary is actually very helpful and makes it easier to perform services, However, based on the results of the author's research, the use of electronic signatures in the city of Surakarta does not work as expected because it faces various obstacles and obstacles, including:

1. It is not easy to change the mindset of officials, individuals and entrepreneurs who are accustomed to using manual signatures.

2. Lack of legal awareness and knowledge of the public and Notaries - Land Deed Making Officials on the importance of limiting face-to-face distance during the current pandemic situation as well as lack of knowledge of the concept and use and security of using cyber notaries and digital signatures

3. There are fears of the legality of electronic signatures and the safety of electronic signatures from counterfeiting.

Responding to the constraints described above, the following authors provide several solutions related to these constraints, including:

1. The use of the concept of cyber notary in service to the applicants.

Cyber notaryis a concept that utilizes technological advances for Notaries to make authentic deeds in cyberspace and carry out their duties every day. For

\footnotetext{
${ }^{6}$ Efa Laela Fakhriah, Electronic Evidence in Civil Evidence Systems, Bandung: PT. Alumni, 2011.
} p.29 
example, the electronic signing of deeds and the General Meeting of Shareholders (GMS) by means of a teleconference. This aims to make it easier for parties who live far apart, so that with the cyber notary, distance is no longer a problem. ${ }^{7}$ Cyber notary is also intended to facilitate or accelerate the implementation of the duties and authority of the Notary in making authentic deeds regarding all actions or agreements or provisions required by law or what the interested parties want to be stated in an authentic deed. The origin of the concept of cyber notary can be traced to two legal systems, namely the common law and civil law systems.

There are two legal terms that are often equated, namely Electronic Notary, (E-Notary) and Cyber Notary ". The first term was introduced by the French delegation in a legal workshop organized by the European Union in 1989 in Brussels, Belgium. In essence, the concept of E-Notary makes a notary a party that presents an independent record of an electronic transaction conducted by the parties. ${ }^{8}$ The notary profession tends to serve the business world, even UUJN states that the number of formations (needs) for notaries in an area is determined based on the activities of the business world, for example: Jakarta as the capital of the country which is also the center of the Indonesian economy is designated as regional formation A by Permenkumham Number 27 of 2016 Formation of Notary Position and Determination of Regional Categories. The meaning of an area that is categorized as "area $A$ " by the government is that the region has more advanced economic activities than other regions (there are 4 categories of regions: $A, B, C$ and $D$ ).

Various arrangements such as online fiduciary registration, electronic HT registration, online legal entity name messages are proof that the business world wants time efficiency and convenience in all matters related to legality aspects. It is hoped that additional regulations regarding the concept of cyber notary in UUJN or established in separate laws and regulations as concrete and formal regulations and accompanied by full support in the form of providing adequate facilities to ensure legal certainty in the implementation of cyber notary in Indonesia.

2. Changing a manual signature to a digital (electronic) signature.

\footnotetext{
${ }^{7}$ Emma Nurita, Cyber Notary Early Understanding in the Concept of Thought, (Bandung: Refika Aditama), 2012, p. 53

${ }^{8}$ Edmon Makarim, Responsibility for Electronic System Operators, Jakarta: Rajawali Pers, 2010, p.
} 40. 
Basically, an electronic signature is the same as a manual signature, an electronic signature is unique, that is, a person's electronic signature will be different from the signature of others. Electronic signature is a combination of a hash function and encryption with an asymmetric method. The hash function is a one-way function and will generate a unique value for each entered data. Therefore, if there is only one bit change in the document content, the resulting hash value will be different. The hash value is then encrypted using a private key, then the value of the encryption result is the signature value of a document.

The legal force and legal consequences of electronic signatures are the same as manual signatures as guaranteed in the explanation of Article 11 of the ITE Law of 2008. Article 1869 in conjunction with Article 1874 of the Civil Code and Article 1 of Ordinance 1867 No. 29 also applies to electronic signatures so that by being given an electronic signature, the electronic document has legal force. By signing, it shows the signatory agreement to the information or electronic document that is signed by it as well as guarantees the accuracy of the content stated in the writing. To be able to have legal force and legal consequences, the electronic signature must meet the requirements in Article 11 paragraph (1) of the ITE Law, namely:

1) Electronic signature creation data related only to the signer;

2) The data for making electronic signatures at the time of the signing process is only in the power of the signing;

3) Any changes to the electronic signature that occur after the time of signing the subscription is known;

4) Any changes to the electronic information associated with the electronic signature after the time of signing the subscription can be known;

5) There are certain ways that can be used to identify who are the subscribers; and

6) There are certain ways to demonstrate that the subscriber has given consent to the associated electronic information.

The socialization that cyber notaries use digital signatures has also been going fast since several years ago, PrivyID's digital signature was mentioned at the plenary meeting of the Indonesian Notary Association, as an alternative solution for notaries to turn into cyber notaries. In the digital signature provided by 
PrivyID, there is a digital certificate to decrypt digital documents in pdf format. This digital certificate contains information on the owner of the signature, such as the population identification number, self-portrait from various sides, up to blood type. So that this digital certificate will be used to prove whether the digital signature is fake or genuine, and whether there are changes to the document when in court. ${ }^{9}$

a) Electronic Signature creation data related only to the Signer;

b) Electronic Signature creation data during the electronic signing process is only in the power of the Signer; c. all changes to the Electronic Signature that occur after the signing time can be known;

c) Any changes to Electronic Information related to the Electronic Signature after the signing time can be known;

d) There are certain methods used to identify who the Signatories are;

e) There are certain ways to show that the Signer has given consent to the related Electronic Information. 2. Further provisions regarding Electronic Signatures as intended in paragraph (1) shall be regulated by Government Regulation.

If it is observed that the use of digital signatures has guaranteed authentication, which can be seen from the hash function in the electronic signature so that the recipient of the data (recipient) can compare the hash value. If the hash value is the same and appropriate, then the data is truly authentic in the sense that there has never been an act of changing the data at the time of transmission, then authentication can be guaranteed. However, if it is not the same or there has been a change in hash value, it is reasonable to suspect that there has been data modification. This is where one of the advantages of electronic signatures compared to manual signatures is that if there is a change in the document, whatever it is in writing (even if it is only 1 character), or metadata, the electronic signature is no longer valid so that the data or document is more secure from modification by unauthorized parties. This of course makes it easier in the proving process compared to a manual signature which requires further examination in the forensic laboratory to prove its authenticity, so that users do not need to worry or hesitate to use it.

${ }^{9}$ https://privy.id/id, accessed on 25 December 2020 at 22.00. 
Observing the developments in the situation of the spread of covid-19 which is increasingly rapidly marked by the appeal of the Government of the Republic of Indonesia to carry out work activities at home only, and efforts to prevent deterrence from breaking the chain of the spread of the covid-19 virus must be carried out in a structured, systematic and massive manner through actions that are consistent with requiring every citizen to always obey and obey every instruction of the Government of the Republic of Indonesia relating to the implementation of efforts to prevent the spread of the Covid-19 virus through the following general policies (public police):

1) Social distancing related to the existence of restrictions on social activities that involve large numbers of people;

2) Public Distancing related to limiting crowd and / or gathering activities that involve large numbers of people;

3) Pshisycal distancingrelated to face-to-face communication which should be done keeping a certain distance of 1 meter.

Reducing the duration of operations at the Notary Office or public service offices, the implementation of this is considered one of the strategies, so that social distancing can be more effective. As for managers of hotel meeting buildings and places of worship, the city government prohibits them from accepting orders or holding activities that have the potential to gather large numbers of people. The restrictions on interaction between visitors were also asked to be implemented in these places. The Surakarta Ministry of Religion (Kemenag) has asked the managers of places of worship to eliminate conventional prayer processions such as Friday prayers, services or mass, so that people do not gather in one place for a relatively long period of time. Because this activity can trigger the transfer of the virus from one person to another around them. To support the educational process in the city of Surakarta to keep running, the Surakarta City Government has also provided mobile phone assistance to support online learning for junior high school students in the city of Surakarta. Mayor of Surakarta, FX. Hadi Rudyatmo said that the distribution of cell phone assistance to support online learning would continue.

Increasing the standard of public services by notaries and agencies will be one of the efforts to prevent the spread of this virus, therefore it is necessary to make massive efforts to prevent an increase in the number of patients. This is in accordance with the Decree of the Minister of Health Number HK.01.07 / MENKES / 382/2020 concerning Protocols for Communities in Public Places and Public Facilities in the Context of Prevention and Control of Covid-19. With the 
use of information technology based on digital transformation, it is hoped that it can support the implementation of public services and still guarantee legal certainty and protection during a pandemic so that it can run optimally.

\section{Closing}

Based on the results of the study, it was concluded that the application of the online system to cyber notary in the city of Surakarta still requires more in-depth dissemination of security and effectiveness in using the online system and cyber notary, as well as the obstacles faced in implementing the online system and cyber notary policies in dealing with the impact of covid. -19 in the city of Surakarta, there are still conflicting rules between Article 15 UUJN and Article 16 UUJN, linked to Articles 11 and 12 of Act No. 11 of 2008 and Act No. 19 of 2016 concerning Electronic Information and Transactions (UU ITE and PUU ITE), as well as a lack of legal awareness and knowledge from the public and PPAT Notaries of the importance of limiting face-to-face distance during the COVID-19 pandemic situation and a lack of knowledge about the concept and use and security of the use of cyber notaries and digital signatures whose use has been guaranteed by the ITE Law and ITE PUU that The printed products of cyber notary are valid evidence and have legal consequences. The suggestions that the writer convey is application The concept of cyber notary can need to be applied in Indonesia, one of which is by removing the clause "before and read by notaries". Law and life must follow the times and technology, how to change clauses in front of them and read them out can only be done by revising Act No. 30 of 2004. When examined and connected with the authority of a notary public, the purpose of cyber notary is to change the way a notary works. A more practical and efficient way of working for people who need notary services. This means that in order to assess what is considered more practical and more efficient, we must know what are the provisions of the current regulation (ius constitutum) and what the public wants.

\section{References}

Journals:

[1] Analysis of the Results of the Socio-Economic Survey of the Impact of Covid-19 in the City of Solo by the Central Statistics Agency (BPS) Solo in July 2020.

[2] Article 1 paragraph 1 Amendment to the Notary Code of Ethics for the Extraordinary Congress of the Indonesian Notary Association, Banten, 2930 May 2015 
[3] Brian Amy Prastyo, Opportunities and Challenges of Cyber Notary in Indonesia, Dwi Merlyani, Annalisa Yahanan, Agus Trisaka, Obligation to Read Authentic Deeds by Notaries in Facing Facers with the Concept of Cyber Notary, Faculty of Law, Sriwijaya University.

[4] Dina Harindra Trisnani- Umar Ma'ruf, The validity of the Notary Agreement Signed Outside the Notary Office, Journal of Deed Master of Notary, Faculty of Law, Sultan Agung University Semarang.

[5] Dwi Merlyani, Annalisa Yahanan, Agus Trisaka, Mandatory Notary Reading of Authentic Deeds in Facing the Audience with the Concept of Cyber Notary, Faculty of Law, Sriwijaya University.

[6] Edi Asrofin-Umar Ma'ruf, Implications of Falsification of Signatures in the Land Sale and Purchase Deed Conducted by PPAT, Journal of Notary Masters Deed, Faculty of Law, Sultan Agung University Semarang.

[7] Luthvi Febryka Nola, Opportunities for the Application of Cyber Notary in Indonesian Legislation, Journal of the State of Law: Vol. 2, No1, June 2011.

[8] Mariam Darus Badrulzaman, Dreaming of the Birth of Cyber Law in Indonesia, (Medan: Pidato Purna Bhakti, 13 November 2001).

[9] Monicha Rossalia Adigita-Umar Ma'ruf-Aryani-Witasari, Role and Protection of the Law to Notaries Regarding Disputes Between the Parties, Journal of Notary Master Deed, Faculty of Law, Sultan Agung University Semarang.

[10] Muhammad Fajar, BUNGA RAMPAI PANDEMI "Uncovering the Social Impacts of Covid-19 Society", IAIN Parepare Nusantara Press 2020.

[11] Raden Hamengku Aji Dewondaru- Umar Ma'ruf, Legal Review of Requirements for Notaries and PPAT who concurrently have a domiciled position in one area or working area, Journal of Deed Master of Notary, Faculty of Law, Sultan Agung University Semarang.

[12] Wa hyu Sasongko, 2007, Basic Provisions for Consumer Protection Law, University of Lampung, Bandar Lampung.

[13] Zainatun Rossalina, et.al, "The Legality of Notary Deed Using Cyber Notary as Authentic Deed" 
Books:

[1] Abdulkadir MuHak Asasi Manusiamad, 2004, "Law and Legal Research", Citra Aditya Bakti, Bandung

[2] Big Indonesian Dictionary, 1989, Writing Team for Dictionary of the Center for Language Development and Development. Jakarta: Balai Pustaka.

[3] CST Kansil and Christine ST, 2009, Principles of Legal Position Ethics, Pradnya Paramita, Jakarta.

[4] Edmon Makarim, 2010, Responsibility for Electronic System Operators, Jakarta: Rajawali Pers.

[5] Efa Laela Fakhriah, 2011, Electronic Evidence in Civil Evidence Systems, Bandung: PT. Alumni.

[6] Emma Nurita, 2012, Cyber Notary Early Understanding in the Concept of Thought, (Bandung: Refika Aditama).

[7] GHS Lumban Tobing, 1992, Third printed Notary Position Regulation, Erlangga, Jakarta.

[8] H. Ustad Adil, SHI, SS, MH, 2011, Getting to know the Notary Syari'ah. Bandung: PT. Citra Aditya Bakti.

[9] Habib Adjie, 2011, Cancellation and Cancellation of Notary Deed, Bandung: PT. Refika Aditama.

[10] Harkristuti Harkrisnowo, 2009, Respect for HUMAN RIGHTS in Facing the Global Crisis, Journal of Human Rights, vol 1, No. 8, Ministry of Law and Human Rights of the Republic of Indonesia, Jakarta.

[11] Hasan, M. Iqbal, 2002, Principles of Research Methodology and Its Application, Ghlmia Indonesia, Bogor.

[12] Hasibuan, Malayu, 2014, Human Resource Management. Jakarta: Earth Literacy.

[13] HB Sutopo, 1998, Introduction to Qualitative Research: Theoretical and Practical Basics. Surakarta: Surakarta Research Center. 
[14] Heri Herdiawanto, 2010, Intelligent, Critical, and Active Citizen. Jakarta: PT. Gelora Script Primary.

[15] Herlien Budiono, Collection of Civil Law Writings in the Notary Sector, Bandung: Citra Aditya Bakti, 2008.

[16] Jimly Asshiddiqie and Hafid Abbas, 2015, Human Rights in the Indonesian Constitution, 5th Printing, Kharisma Putra Utama, Jakarta.

[17] John W Creswell, 1993, Research Design: Qualitative \& Quantitative Approach. London: Sage.

[18] Jumadi, 2012, Reflections on Human Rights in Indonesia. Makassar: Alauddin University press.

[19] Kancil CST, 1989, Introduction to Indonesian Law and Law Administration, Balai Pustaka, Jakarta.

[20] Komar Andasasmita, 1981, Notary With History, Role, Duties and Obligations, Secret Position, Sumur, Bandung.

[21] Lexy J. Maleong. 2005. Qualitative Research Methods (revised edition). Bandung: PT Remaja Rosdaka.

[22] M. Ali Zaidan, 2015, Towards a Change in Criminal Law, Sinar Grafika, Jakarta.

[23] M. Luthfan Hadi Darus, 2017, Notary Law and Responsibilities of the Position of Notary Public. Yogyakarta: Uii Press.

[24] Mansour Effendi, 1994, Dimensions and Dynamics of Human Rights in National and International Law, Gha lia Indonesia, Jakarta.

[25] Ministry of Law and Human Rights Republic of Indonesia Directorate General of Human Rights, 2010, Human Rights for All, 2nd Printing, Jakarta.

[26] Ministry of Religion of the Republic of Indonesia, 2012, Al Baqarah (2) verse 282, Al-Qur'an and its translation (Bandung: PT. Mizan Buaya Kreativa). 
[27] onny Haniatjo Soemitro, 1990, Legal and Jurumetric Research Methods. Jakarta: PT Ghlmia Indonesia.

[28] Philipus M. Hadjon, 1987, Legal Protection for the Indonesian People, Surabaya: Bina Ilmu.

[29] R. Soegondo Notodisoerjo, 1993, Notariat Law in Indonesia An Explanation, Rajawali Pers. Jakarta.

[30] Ramd Ian Naning, 1983, The Idea and Image of Human Rights in Indonesia, Liberty, Yogyakarta.

[31] Riduan Syahrani, 1999, Summary of the Essence of Law, Bandung: Citra Aditya Bakti.

[32] Satjipto Raharjo, 2009, Layers in Legal Studies, Bayumedia, Malang.

[33] Soerjono Soekamto, 2014, Introduction to Legal Research., University of Indonesia, Jakarta.

[34] Subekti, 1984, Principles of Civil Law, Eighteenth Printing. Jakarta: PT Intermasa.

[35] Sudikno Mertokusumo, 1999, Getting to Know the Law for Introduction, Liberti, Yogyakarta.

[36] Tan Thong Kie, 2011, Study of Notaries and the Practices of Notary Public, Jakarta: PT. Van Hoeve's New Ichtiar.

[37] Wahbah Az-zuhaili, 2005, Freedom in Islam. Jakarta: Pustaka AlKautsar.

[38] Yovita A. Mangesti and Bernard L. Tanya, 2014, Morality of Law, Yogyakarta: Genta Publishing.

\section{Regulations:}

[1] As well as the Joint Decree of the Chief Justice of the Supreme Court and the Minister of Justice Number KMA / 006 / SKB / VII / 1987

[2] Circular Letter of the Supreme Court of the Republic of Indonesia Number 2 of 1984

[3] Civil Code Article 1868 
[4] Decree of the Minister of Justice of the Republic of Indonesia Number C2-0221.HT.01.06 of 1995 and Number 28 Supplement No.1 / P-1995,

[5] Decree of the Minister of Law and Human Rights of the Republic of Indonesia 12 January 2009 Number AHU03.AH.01.07.Tahun 2009.

[6] Government Regulation Number 82 of 2012

[7] Information and Electronic Transactions Law Article 1 Paragraph (12) of Law 11/2008

[8] Law on Notary Position Article 15 with Article 16

[9] Mayor of Surakarta Circular Number 067/3189, 067/3205, 510/708, dated March 24, 2020.

[10] Stipulation of the Minister of Justice dated December 4, 1958 Number JA5 / 117/6 and State Gazette of the Republic of Indonesia dated March 6, 1959 Number 19

[11] The Constitution of the Republic of Indonesia Article 52 letter a Number 24, Article 54 letter J Number 24 of 2009

[12] The Constitution of the Republic of Indonesia Number 19 of 2016

[13] The Constitution of the Republic of Indonesia Number 2 of 2014

[14] The Constitution of the Republic of Indonesia Number 30 of 2004

[15] The Constitution of the Republic of Indonesia Number Articles 11 and 1211 of 2008

Internet:

[1] https://www.solopos.com/dampak-covid-19-pendapatan-warga-soloturun-49-pengektronik-naik-25-1078346/, accessed December 24, 2020.

[2] https://www.gatra.com/detail/news/481864/ekonomi/pandemi-covid19-solo-alami-deflasi-berturut-turut/, accessed December 24, 2020.

[3] https://jatengprov.go.id/beritadaerah/pemkot-surakarta-matangkanpers]-pembelajaran-tatap-muka//, accessed 25 December 2020.

[4] http://staff.blog.ui.ac.id/brian.amy/2009/11/29/peluang-cyber-notary-diindonesia/, accessed December 23, 2020.

[5] https://dispendukcapil.surakarta.go.id/wpcontent/uploads/2019/09/prof il_201802_ska.pdf/, accessed on 23 December 2020.

[6] https://privy.id/id, accessed December 25, 2020. 
[7] https://surakarta.go.id/?page_id=10806, accessed January 2, 2021.

[8] https://adalah.co.id/teleconference/, accessed on 19 December at 6:45 p.m 